\title{
Effect of the Map Knowledge and Practice Course in Social Studies Teaching on the Development of Map Literacy Skill
}

\author{
Servet HALì1 \\ Hatay Mustafa Kemal University, Hatay, TURKEY
}

${ }^{1}$ Assoc. Prof.; Mustafa Kemal Üniversitesi, Eğitim Fakültesi Türkçe Eğitimi Bölümü Tayfur Sökmen Kampüsü Alahan-Antakya/HATAY TURKEY. s.hali [at] hotmail.com. ORCID: 0000-0002-3365-0937

\begin{abstract}
This study attempts to investigate the effect of the Map Knowledge and Practice course, which is among the specialized field courses that Social Studies Teachers have studied during the undergraduate education process, on the development of "map literacy skills" in the Introduction to Science and Social Studies Curriculum. Map use for space perception during the teaching of History and Geography subjects included in the Social Studies Education curriculum has an impact on the realization and permanence of teaching, which makes map literacy skills important and crucial in Social Studies Teaching. Many topics, especially in history, geography and social sciences in general, therefore, require knowledge and skills of map literacy. This research studied with social studies teachers working in the province of Hatay. Quantitative research was applied as a data collection method in this study and the questionnaire "The Effect of Map Knowledge and Practice Course on Map Literacy Skill" was implemented to obtain data on the mapliteracy skill of social studies teachers working in Hatay. A pilot study was employed to 56 social studies teachers so as to calculate the validity and reliability of the questionnaire and the Cronbach Alpha internal consistency coefficient of the 17-item questionnaire was calculated as .91. The findings revealed that the undergraduate course Map Knowledge and Practice was found to have a positive effect on mapping ability, especially in detecting location on a map, perceiving spatial distribution, comprehending the landforms, interpretation maps, and sense of direction.
\end{abstract}

\section{Keywords}

Social Studies, Map Knowledge, Map, Map Literacy

To cite this article: Hali, S. (2021). Effect of the map knowledge and practice course in social studies teaching on the development of map literacy skill. Review of International Geographical Education (RIGEO), 11(3), pp-pp. doi: 10.33403rigeo.859216 
Paykoç (1991) describes the concept of skills, which has been widely adopted today, is as "the ability to do any activity continuously at a certain level of competence". Cognitive skills, which are divided into sequential classes by Bloom as a prerequisite for each other, are integral parts of the curriculum and improved by adding new ones to the previously determined skill content and skill areas (Demiralp, 2006). Social Studies can be defined as a branch of science that takes the socialization process into account. Social Studies, in that sense, is a field of science that equips students with the knowledge, skills, attitudes, and values required to produce solutions to social problems and to participate in the socialization process, and thereby, the curriculum should be planned accordingly (Otluoğlu \& Öztürk, 2003; Aydın et al .., 2013). As an interdisciplinary science, Social Studies Teaching attempts to make students competent in Geography and History, especially in using map skills. The definition of social studies in the Social Studies program is as follows:

"Social Studies is a primary education lesson developed on the basis of collective education understanding, reflecting social sciences and citizenship subjects such as history, geography, economics, sociology, anthropology, psychology, philosophy, political science, and law, combining learning areas under a unit or theme; investigating the interaction of individuals with their social and physical environment in the context of past, present, and future so as to help individuals to realize their social existence" (MoNE. 2006: 26).

Regarding this definition, history and geography are among the basic disciplines in the social studies course. Karabağ (1998: 38-39) classifies map skills as primary and secondary skills, as well as direct or indirect skills. Although geographical skills are prominent in using maps, Karabağ (2001: 64) mentions these skills as "activities related to mapping and field studies. These skills are such topics as plan, map, globe, atlas, coordinates, symbol use, and orientation. Computer use, which is increasingly regarded as a crucial skill, is also considered within the geographical skills. With the constantly developing technology, skills involve a process that is constantly evolving.

Hart and Dunbar (1994: 1), one of the researchers working in this field, list the skills as follows:

1. Geography-related techniques or techniques used in geography,

2. Map skills,

3. Gathering information,

4. Information processing or information processing process,

5. The process of presenting information

This research focuses on the ability of map using, one of those skills,

In our research, one of these skills will be focused on the ability to map use as map studies are the primary focus of geographic studies and maps are the major tool of geography. However, this idea should not be addressed in a narrow scope as, stated by Gürsoy (1961), maps are the most required materials of geography. Developing, using, and interpreting maps are also crucial and require an experience that is interwoven with many compulsory sub-skills (Karabağ, 1998: 39). In a 
similar vein, Gürsoy (1961) expresses that "map has an important place in geography teaching regarding the fact that geography is the knowledge of the earth, that is, of space. In geography, the earth is not only a two-dimensional surface but also a site or place with a third dimension".

Constituting an important part of Social Studies, geography focuses on human activities in space in different dimensions. Regardless of the country, people want to learn about the place they live in and they need to learn about the geography they live in. Maps are the main source of spatial information on geography. Maps, then, are the most important tools for the development of students' spatial perception skills (Kızılçaoğlu, 2007: 351).

Bircan and Safran (2013) state that geographical conditions shape history, foster its development, and all human life is investigated regarding this geographical environment, and therefore, interdisciplinary studies of history and geography will provide certain benefits to education and training. Starting with the Life Sciences and Social Studies courses and separated as History and Geography at the level of secondary education, Social Studies courses should be the focus of interest with regards to both the subject area and materials development in teaching. Fostering the persecution of space, maps, in that sense, are regarded as the most important materials in history teaching to comprehend facts and events.

\section{Map Skills}

Maps are the most indispensable tool of social sciences based on the fact that they foster the visualization of space. Buğdaycı (2012) expresses that maps are the means of presenting visuals of environmental data collected by disciplines such as geodesy, geography, earth sciences, and atmosphere. He also explains that maps are the products facilitating users' interaction with intensive and complex information and leading the analysis of the geographic information obtained on it. Therefore, developing map skills gains a curial matter, and teachers are suggested to plan and implement different activities to gain knowledge, skills, values, and attitudes anticipated in the outcomes along with the activities that the curriculum has already offered (MoNE, 2005a).

Building, using, and interpreting maps requires certain skill (Koç et al., 2017), in that, as Sönmez and Aksoy (2013) put it, acquiring geographic skills in learning and teaching activities in social studies lesson, and accordingly, primary school students' mapping skills bear importance to primary school students as mapping skills attempt to perceive, recognize and make sense of the environment in which individuals live. In that vein, the student-centered approaches and the use of methods and techniques accordingly are highly suggested (Sönmez \& Aksoy, 2013: 270). Maps are considered as the major tools for permanent learning in social sciences, in which they ease the learning of challenging subjects through adding visuality, foster learning new information, and create peripheral learning spaces for learners through examining a wall map in the classroom (Zaman et al. 2011: 206207).

Koç (2017) describes the activities with using maps and map skills (the ability to choose an appropriate map, detecting location and direction through maps, 
determining location, making calculations such as distance, area, and slope, analyzing and interpreting natural, human and economic events, facts, and features that are distributed on the plane, and transferring scattered events, facts, and features onto the plane using appropriate symbols, etc.) as a set of spontaneous abilities.

The skills of map literacy are also among the main skills in the Social Studies Curriculum, and acquiring map skills in the geography curriculum is required to develop map literacy (Sönmez \& Aksoy, 2013). Although the concept of literacy originally refers to reading and writing skills, its scope has expanded over time. After the industrial revolution, this concept is addressed to being well-educated in a certain field or having a broad knowledge of a certain field (Koç et al., 2017: 303). The literature describes these skills as follows:

a) Detecting location on the map

b) Transferring information on the map

c) Choosing a map suitable for its purpose

d) Making calculations using maps, using scales

e) Perceiving spatial distribution, understanding landforms

f) Correct interpretation of the map

g) Creating draft maps

h) Sense of direction (Akar, 2008; Buğdaycı \& Bildirici; 2009; Demiralp, 2009; Kızılçaoğlu, 2007; Koç \& Aksoy, 2009; Sönmez, 2010; Sönmez \& Aksoy, 2013).

It is of great importance that both pre-undergraduate and undergraduate students gain mapping skills so as to better understand the environment and the world they live in; therefore, students should be trained to have basic mapping skills and detect any place, including their living place and interpret maps. They also should be able to better comprehend daily events in the context of the space where they take place and use thinking skills to make a better decision on the issues they encounter in their daily lives (Akkuş \& Kuzey, 2018: 206).

Studies in the literature highlight the importance of visual descriptions as a means of learning; thus, equipping learners with map skills constitutes one of the most important goals and visions of social studies secondary education, history, and geography teaching which have been gradually implemented by the Ministry of National Education since 2005, as in all social studies secondary education programs (İncekara et al., 2008: 98).

The advantages of information technologies to visuality increase the importance of visual elements in education (Aksoy \& Ünlü, 2012: 19). Maps are among the easiest to find educational tools. Thanks to the map and related visuals, students can interpret the symbols and easily learn the relationship between landforms, climate, settlement, and distance. They can easily observe the size and location of their countries, realize their relations with each other, and make inferences about their geographic locations (Ünlü et al. 2002). Besides, Ünlü (2011) expresses that map 
skills lead learners to comprehend basic characteristics of settlements and detect their distance from other centers.

Individuals who have acquired map skills can play important roles for themselves and their environment as all the events we experience take place in space. The map skill, which refers to the knowledge of space and is acquired within the scope of geography and Social studies lessons, which means knowledge of space, provides information about the space. The more an individual understands the living environment, the more easily he can perceive and analyze the spatial information. Thus, an individual with mapping skills does not experience any difficulty in creating mind maps and gains a geographical awareness (Bahar, Sayar \& Başıüyük, 2010; cited in Fesliyen et al. 2019).

Teachers have an enormous role in the learning and teaching process and should enrich the content of the teaching process with in-class and out-of-class activities and a wide variety of materials to achieve the objectives of the curriculum. Effective use of maps depends on teachers' competence of map knowledge and their experience. In addition to the quality of the maps, the teachers must be conscious and willing to use and teach maps in their lessons (Buğdaycı \& Bildirici, 2009).

\section{Purpose of the Study}

Map literacy skills become a crucial matter regarding the influence of map use on the realization and permanence of learning in the teaching of History and Geography subjects included in the Social Studies Education curriculum. Therefore, many topics especially in history, geography, and social sciences in general demand map literacy knowledge and skills. The literature in Turkey does not include many studies determining teachers' knowledge and competence map use, which makes studying learners' map skills and sense of direction and overcoming the deficiencies in that regard, if any, even more significant. The importance of map skills both in lowerand upper-secondary education lays in the possibility to foster the ability to comprehend and interpret the geography and the world we live in, as well as map skills, are of great importance for other disciplines and skills. To equip learners with those skills, pre-service teachers should first acquire those information and skills so that they can teach. Therefore, this study attempted to examine the effect of the Map Knowledge and Practice course, which pre-service social studies teachers took in their undergraduate education, on the development of map literacy skills included in the Life Sciences, primary and lower-level secondary school Social Studies Education curriculum.

To conclude, this study sought to answer the research question 'What is the effect of the course of Map Knowledge and Practice in Social Studies teaching on map literacy skill?' regarding the variables of gender, professional experience, graduated faculty and department, education level.

\section{Methodology}

This study was guided by a descriptive survey design, which is one of the survey designs. The survey model is a method conducted on the whole universe or a group or sample to be taken from it to make a judgment about the universe consisting of many elements and data. On the other hand, the descriptive survey design attempts 
to define the event, person, or object as a whole and carefully (Karasar, 2010: 79; Gay, Mills \& Airasian, 2012: 18).

\section{Participants}

Social studies teachers working in state schools affiliated to the Hatay Provincial Directorate of National Education in the 2020-2021 academic year following the principle of convenience sampling. 130 of 827 Social studies teachers within the borders of Hatay Province could be reached for the purpose of the study.

\section{Data Collection Tools}

The study employed the questionnaire "The Effect of Map Knowledge and Practice Course on Map Literacy Skill" to social studies teachers working in Hatay

\section{Data Collection Procedure and Data Analysis}

The questionnaire named "The Effect of Map Knowledge and Practice Course on Map Literacy Skills" was developed by the researcher. The questionnaire consisted of two parts, in that the first parts included demographic information of the participants (age, gender, department, etc.) while the second part consisted of statements about social studies teachers' map knowledge and practices and their effect on map literacy skills. The validity and reliability coefficients of the questionnaire were run by employing the questionnaire to a pilot study group of 56 people and the Cronbach Alpha internal consistency coefficient of the 17-item questionnaire was calculated as .91.

The obtained data from the questionnaire was analyzed through the SPSS 22 and the results were interpreted. The general evaluation of the questionnaire employed in the study as follows (Sarıöz et al., 2015; Dönger, Özkartal, Sarıgöz, 2016):

$$
\mathrm{RV}=\frac{\mathrm{HV}-\mathrm{LV}}{\mathrm{SV}}=\frac{5-1}{5}=0.8
$$

RV: Range of values

HV: The Highest Value

LV: The Lowest Value

SV: Number of Values

1.00 - 1.80: Totally disagree

1.81 - 2.60: Disagree

2.61 - 3.40: Neutral

3.41 - 4.20: Agree

4.21 - 5.00: Totally Agree

\section{Results and Discussion}

Table 1 shows no statistically significant difference ( $p>.05$ ) between female teachers and male teachers regarding participants' gender. The views of female teachers and male teachers on the effect of the Map Knowledge and Practice Course on Map Literacy Skills, then, could be stated to be. Using a map as a geography- 
Hali, S. (2021). Effect of the map knowledge and practice course in social studies teaching on the.....

specific source of information is one of the essential components of teaching geography.

Table 1

The findings of ANOVA regarding gender variable

\begin{tabular}{lllllll}
\hline Gender & $\mathrm{N}$ & $\overline{\mathrm{X}}$ & $\mathrm{Ss}$ & $\mathrm{Sd}$ & $-\mathrm{t}$ & $\begin{array}{l}\mathrm{P} \\
\text { (Anova) }\end{array}$ \\
\hline Female & 57 & 68.88 & 8.12 & \multirow{2}{*}{128} & 1.072 & .286 \\
\cline { 1 - 4 } & 73 & 65.73 & 10.87 & & $\mathrm{p}>0.05$ \\
\hline Total & 130 & & & & \\
\hline
\end{tabular}

Based on the ANOVA analysis regarding the responses of teachers with different age groups, they were found to share similar views on the effect of the Map Knowledge and Practice course on map literacy skills.

Table 2

The Findings of ANOVA Regarding Age Variable

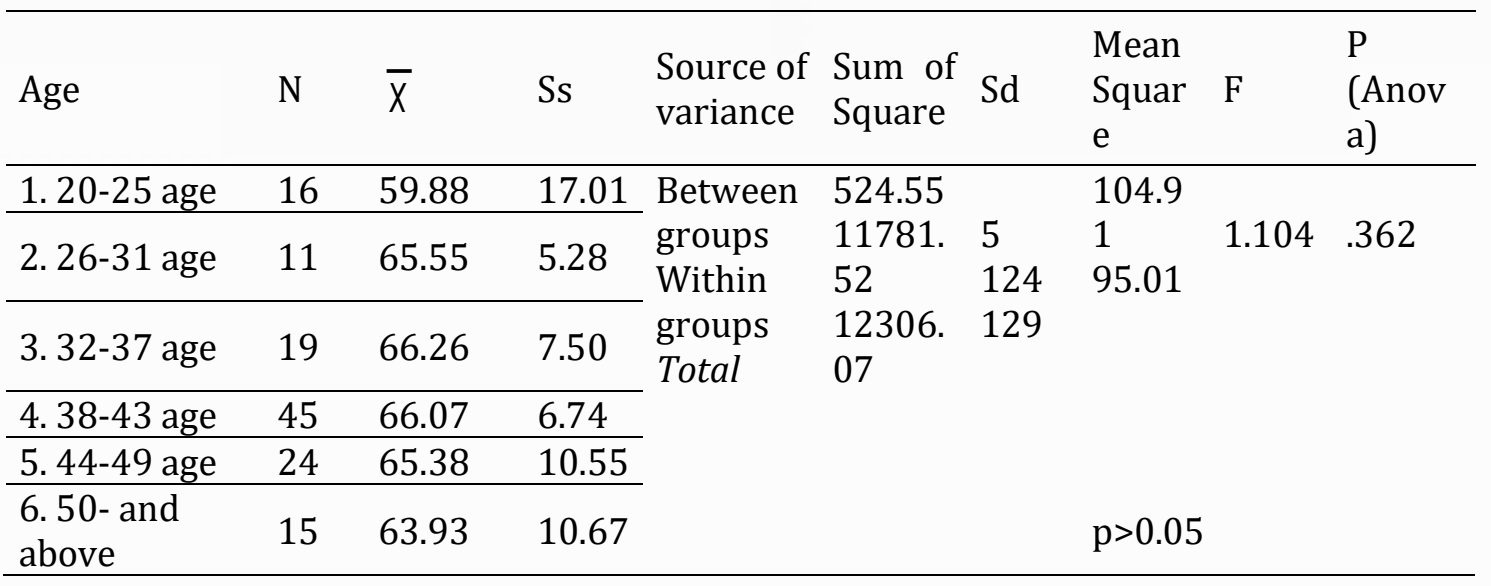

Table 3

The Findings of ANOVA Regarding Graduated Faculty Variable

\begin{tabular}{|c|c|c|c|c|c|c|c|c|c|}
\hline $\begin{array}{l}\text { Graduated } \\
\text { Faculty }\end{array}$ & $\mathrm{N}$ & $\bar{x}$ & Ss & $\begin{array}{l}\text { Source of } \\
\text { variance }\end{array}$ & $\begin{array}{l}\text { Sum of } \\
\text { Square }\end{array}$ & Sd & $\begin{array}{l}\text { Mean } \\
\text { Square }\end{array}$ & $\mathrm{F}$ & $\begin{array}{l}\mathrm{P} \\
\text { (Anova) }\end{array}$ \\
\hline $\begin{array}{l}\text { 1. Fac. of } \\
\text { education. }\end{array}$ & 92 & 65.14 & 9.81 & \multirow{3}{*}{$\begin{array}{l}\text { Between } \\
\text { groups } \\
\text { Within } \\
\text { groups } \\
\text { Total }\end{array}$} & & & 28.02 & \multirow{3}{*}{.290} & \multirow{3}{*}{.748} \\
\hline $\begin{array}{l}\text { 2. fac. of arts } \\
\text { and sciences }\end{array}$ & 32 & 64.81 & 10.47 & & $\begin{array}{l}56.03 \\
12250.04 \\
1230607\end{array}$ & $\begin{array}{l}2 \\
127 \\
129\end{array}$ & 96.46 & & \\
\hline $\begin{array}{l}\text { 3. Institute of } \\
\text { Education }\end{array}$ & 6 & 62.00 & 4.52 & & & & $\mathrm{p}>0.05$ & & \\
\hline
\end{tabular}

Table 3 indicates the responses of teachers who graduated from different faculties to the effect of Map Knowledge and Practice course on the map literacy skills, in which they were observed to have similar views. 
Table 4

The Findings of ANOVA Regarding Professional Experience Variable

\begin{tabular}{|c|c|c|c|c|c|c|c|c|c|}
\hline $\begin{array}{l}\text { Professional } \\
\text { experience }\end{array}$ & $\mathrm{N}$ & $\bar{x}$ & Ss & $\begin{array}{l}\text { Source of } \\
\text { variance }\end{array}$ & $\begin{array}{l}\text { Sum of } \\
\text { Square }\end{array}$ & $\mathrm{Sd}$ & $\begin{array}{l}\text { Mean } \\
\text { Square }\end{array}$ & $\mathrm{F}$ & $\begin{array}{l}\mathrm{P} \\
\text { (Anova) }\end{array}$ \\
\hline 1. $1-5$ years & 28 & 62.32 & 13.33 & \multirow{5}{*}{$\begin{array}{l}\text { Between } \\
\text { groups } \\
\text { Within } \\
\text { groups } \\
\text { Total }\end{array}$} & \multirow{5}{*}{$\begin{array}{l}353.89 \\
11952.18 \\
12306.07\end{array}$} & \multirow{4}{*}{$\begin{array}{l}4 \\
125 \\
129\end{array}$} & 88.47 & \multirow{4}{*}{.925} & \multirow{5}{*}{.452} \\
\hline 2. 6-10 years & 18 & 65.61 & 7.41 & & & & 95.61 & & \\
\hline 3. $11-15$ years & 27 & 65.67 & 7.67 & & & & & & \\
\hline 4. $16-20$ years & 16 & 67.88 & 6.03 & & & & & & \\
\hline $\begin{array}{l}5 . \quad 21 \text { and } \\
\text { above }\end{array}$ & 41 & 64.73 & 10.18 & & & & $p>0.05$ & & \\
\hline
\end{tabular}

Table 4 shows the responses of teachers to the questionnaire regarding the professional experiences, in that teachers with different professional experiences shared similar views on the effect of the Map Knowledge and Practice course on the map literacy skills.

Table 5

The Findings of ANOVA Regarding Graduated Department Variable

\begin{tabular}{|c|c|c|c|c|c|c|c|c|c|}
\hline $\begin{array}{l}\text { Graduated } \\
\text { department }\end{array}$ & $\mathrm{N}$ & $\bar{x}$ & Ss & $\begin{array}{l}\text { Source of } \\
\text { variance }\end{array}$ & $\begin{array}{l}\text { Sum of } \\
\text { Square }\end{array}$ & Sd & $\begin{array}{l}\text { Mean } \\
\text { square }\end{array}$ & $\mathrm{F}$ & $\begin{array}{l}\mathrm{P} \\
\text { (Anova) }\end{array}$ \\
\hline $\begin{array}{l}\text { 1. History } \\
\text { teaching }\end{array}$ & 20 & 64.20 & 4.84 & \multirow{5}{*}{$\begin{array}{l}\text { Between } \\
\text { groups } \\
\text { Within } \\
\text { groups } \\
\text { Total }\end{array}$} & \multirow{5}{*}{$\begin{array}{l}647.56 \\
11658.51 \\
12306.07\end{array}$} & \multirow{4}{*}{$\begin{array}{l}4 \\
125 \\
129\end{array}$} & \multirow{4}{*}{$\begin{array}{l}161.89 \\
93.27\end{array}$} & \multirow{4}{*}{1.736} & \multirow{5}{*}{.146} \\
\hline $\begin{array}{l}\text { 2. Geography } \\
\text { teaching. }\end{array}$ & 12 & 69.67 & 13.87 & & & & & & \\
\hline $\begin{array}{l}\text { 3. Social } \\
\text { Studies } \\
\text { teaching }\end{array}$ & 65 & 64.37 & 9.77 & & & & & & \\
\hline 4. History & 22 & 62.41 & 11.33 & & & & & & \\
\hline 5. Geography & 11 & 69.27 & 5.41 & & & & $\mathrm{p}>0.05$ & & \\
\hline
\end{tabular}

Table 5 indicates the findings of the questionnaire regarding the variable of the graduated department, in which teachers with different fields were found to share similar views on the effect of the Map Knowledge and Practice course on the map literacy skills.

Table 6

The Findings of ANOVA Regarding the Education Level Variable

\begin{tabular}{|c|c|c|c|c|c|c|c|c|c|}
\hline Education level & $\mathrm{N}$ & $\bar{x}$ & Ss & $\begin{array}{l}\text { Source } \\
\text { of } \\
\text { variance }\end{array}$ & $\begin{array}{l}\text { Sum of } \\
\text { Square }\end{array}$ & Sd & $\begin{array}{l}\text { Mean } \\
\text { square }\end{array}$ & $\mathrm{F}$ & $\begin{array}{l}\mathrm{p} \\
\text { (Anova) }\end{array}$ \\
\hline 1.Undergraduate & 109 & 64.75 & 10.14 & \multirow{3}{*}{$\begin{array}{l}\text { Between } \\
\text { groups } \\
\text { Within } \\
\text { groups } \\
\text { Total }\end{array}$} & & & 10.67 & \multirow{3}{*}{.110} & \multirow{3}{*}{.896} \\
\hline 2. Master & 19 & 65.63 & 8.04 & & 21.34 & 2 & 96.73 & & \\
\hline 3.Ph.D. & 2 & 67.00 & 4.24 & & $\begin{array}{l}12284.73 \\
12306.07\end{array}$ & $\begin{array}{l}127 \\
129\end{array}$ & $\mathrm{p}>0.05$ & & \\
\hline
\end{tabular}


Hali, S. (2021). Effect of the map knowledge and practice course in social studies teaching on the.....

Table 6 revealed the views of the teachers with different education levels and the findings of ANOVA indicated similar views on the effect of the course on the map literacy skills.

Table 7

The Arithmetic Means of the Statements of the Questionnaire "The Effect of Map Knowledge and Practice Course on Map Literacy Skills"

\begin{tabular}{lll}
\hline Items & Arithmetic mean $(\bar{x})$ & Standard Deviation (Ss) \\
\hline S1 & 3.2385 & 1.31068 \\
\hline S2 & 3.6308 & 1.18216 \\
\hline S3 & 3.6538 & 1.15276 \\
\hline S4 & 4.0923 & .76195 \\
\hline S5 & 4.3385 & .84039 \\
\hline S6 & 4.2308 & .81210 \\
\hline S7 & 4.2000 & .86625 \\
\hline S8 & 3.7538 & 1.04222 \\
\hline S9 10 & 3.7615 & 1.04773 \\
\hline S11 & 4.2846 & .75979 \\
\hline S12 & 4.2308 & .77298 \\
\hline S13 & 4.2077 & .88656 \\
\hline S14 & 4.1923 & .86353 \\
\hline S15 & 4.3077 & .75582 \\
\hline S16 & 4.2846 & .72854 \\
\hline S17 & 2.5846 & 1.05496 \\
\hline
\end{tabular}

Depending on the arithmetic mean of the scale items, the arithmetic means of the responses to the $1^{\text {st }}, 16^{\text {th }}$, and $17^{\text {th }}$ questionnaire items were found to be lower than other items The arithmetic mean of the responses the first item of the scale (I learned mapping techniques in the course of map knowledge and practice) was observed to be 3.2385 , which showed that teachers responded this item as neutral about learning mapping techniques in the undergraduate process. Therefore, the teachers could be indicated to be inadequate in learning mapping techniques in the course of mapping practices. The arithmetic mean of the sixteenth item of the questionnaire (I don't get bored of reading a book about maps was observed to be 2.5846, which suggested that social studies teachers were getting bored when reading about maps. Besides, the arithmetic mean of the seventeenth item of the questionnaire (I get annoyed when learners ask questions about maps) was found to be 1.9231, which implied that the teachers participating in this study did not experience any difficulties when learners asked questions about maps.

The arithmetic means of the responses to the items of $5^{\text {th }}, 10^{\text {th }}, 14^{\text {th }}$, and $15^{\text {th }}$ in the questionnaire, on the other hand, were observed to be higher than other items. The arithmetic mean of the fifth item (I can find a place on the map by looking at the map) had the highest average, which was found to be 4.3385. This suggested that social studies teachers managed to find a place with their education in the Map Knowledge and Practice course. Based on the arithmetic mean of the tenth item (4.2846), the participants were found to have reached the ability to interpreting maps. Regarding the fourteenth item, social studies teachers were observed to learn 
about the position of a country in the world through their learning in the Map Knowledge and Practice course.

\section{Conclusion and Implications}

The results of the study revealed that similar responses of the social studies teachers to the questionnaire "Effect of Map Knowledge and Practice Course on Map Literacy Skills" regarding their demographic information, which suggested that teachers effectively utilize maps in their teachings thanks to the course Map Knowledge and Practices. Therefore, practices about map use in the undergraduate programs can be suggested to be increased and employed adopting the improvements in technology. The study of Koç, Aksoy, and Çiftçi (2017) revealed that male undergraduate students had higher levels of map knowledge and skills, and map literacy skills than female students.

Teachers participating in the research were found to respond as neutral to the statement about learning mapping techniques during undergraduate education, which implied certain problems about both the content of the course and the quality of the teaching. Thus, the teaching of the Map Knowledge and Practice course provided in the undergraduate programs and the content of other related courses can be suggested to be enriched to maximize learning about maps. In a similar vein, the study of İncekara and Kantürk (2010) on mapping techniques emphasized rearrangements and improvements in teaching maps from primary education to higher education. In his study on attitudes and behaviours of teachers towards the use of maps by age, Duman (2011) also concluded that the age group that made a difference was teachers under the age of thirty.

Considering the responses to the questionnaire items on map skills, the Map Knowledge and Practices course in the undergraduate program provided a positive effect on pre-service teachers' determining locations on a map, perception of spatial distribution and understanding of landforms, interpreting maps, and improving the sense of direction. Therefore, the results concluded that the course plays a crucial role in teacher education programs. Yet, the required theoretical and practical studies are suggested to be conducted to have a whole understanding of map skills. In that regard, Duman (2011) revealed that teachers did not receive sufficient training in map use at their departments and suggested in-service training, courses, and seminars as useful ways of improving teachers' and pre-service teachers' map skills. The studies in the literature and this current research suggest increasing the number of practice-oriented studies in the undergraduate programs regarding the improvement of map skills and practice-oriented studies to improve in-service teachers' map skills. In addition, in-service training at regular intervals is highly suggested to equip teachers with the necessary skills to use technology in their teachings of maps.

\section{References}

Akar, B. (2008). The evaluation of the map using ability of 6th grade students and evaluation of the thoughts of the teachers about the map using abilities of students (Unpublished Master Thesis). Institute of Social Sciences, Mustafa Kemal University, Hatay, Turkey. 
Akkuş, Z. \& Kuzey, M. (2018). An examination of having map and direction skills of middle school students and implementing these skills to their life. Millî Eğitim, 218, 201233.

Aksoy, H. \& Ünlü, M. (2012). Effect of student attitudes applications ability maps in geography lesson. International Journal of Geography and Geography Education, 26, 16-41.

Aktürk, V., Yazıcı, H. \& Bulut, R. (2013). The effects of the use of animations and digital maps in social studies on students' spatial perception skills. International Journal of Geography and Geography Education, 28, 1-17.

Bahar, H. H., Sayar, K. \& Başıüyük, A. (2010). The study of sketch map reading skills of the students in primary school (Erzincan sample). Firat University Journal of Social Sciences, 20(1), 229-246.

Bircan, T.SS. \& Safran, M. (2013). The usage and the importance of maps in teaching history. KEFAD, 14(2), 461-476.

Buğdaycı, İ. \& Bildirici, İ. Ö. (2009). The importance of map use in geography education. 12. Turkey Scientific and Technical Mapping Congress, CD, Ankara.

Buğdaycı, İ. (2012). An evaluation about map use in elementary schools (Unpublished Doctoral Dissertation). Institute of Science, Selçuk University, Konya, Turkey.

Demiralp, N. (2006). Map and glob skills in geography education. Gazi University Journal of Turkish Educational Sciences, 3(4), 323-343.

Demiralp, N. (2006). The development of map and glob skills by the use of demonstration method in geography education (Unpublished Doctoral Dissertation). Institute of Educational Sciences, Gazi University, Ankara, Turkey.

Demiralp, N. (2009). Learning through maps, Journal of Turkish Educational Sciences, 7(4), 955-973.

Dönger, A., Özkartal, Z. \& Sarıgöz, O. (2016). An investigation into variables that affect self efficacy beliefs of people working in educational institutions. International Refereed Academic Social Sciences Journal, 24, 1-17.

Duman, H. (2011) Using map in teaching of social studies and teachers' opinions about using map (Unpublished Master Thesis). Institute of Educational Sciences, Uludağ University, Bursa, Turkey.

Fesliyen, Z., Şanlı, C. \& Pınar, A. (2019). An action research on map reading skill levels of secondary school students: A Kulu sample. Future Visions Journal, 3(3), 9-23.

Gay, L. R., Mills, G. E. \& Airasian, P. W. (2011). Educational research: Competencies for analysis and applications. London: Pearson.

Gürsoy, C.R. (1961). Cartography. Faculty of Languages and History-Geography, 87.

Harte, J. \& Dunbar C. (1994). Skills in geography. Cambridge: Cambridge University.

İncekara, S. \& Kantürk, G. (2010). The conception of maps among the teacher candidates of social sciences and their approaches to using maps. International Journal of Geography and Geography Education, 21, 240-257.

İncekara, S., Karatepe, A. \& Karabun, A. (2008). An application about how to teach topographic map reading with GIS in secondary school geography courses. International Journal of Geography and Geography Education, 17, 97-110. 
Karabağ, S. (1998). Coğrafya öğretiminde anahtar sorular ve kavramlar. Journal of Gazi Educational Faculty, 18(2), 25-41.

Karabağ, S. (2001). İlköğretim sosyal bilgiler konularında coğrafyanın içeriği, ders kitabı inceleme kılavuzu. Ankara: Nobel Yayın Dağıtım.

Karasar, N. (2006). Bilimsel araştırma yöntemi. Ankara: Nobel Yayın Dağıtım.

Kızılçaoğlu, A. (2007). Harita becerilerine pedagojik bir bakış. Selçuk University Journal of Social Sciences, 18, 341-358.

Koç, H. (2017). Coğrafya öğretimin haritalar ve atlasların kullanımı. In A. Sever (Eds), Coğrafya ögrretim teknolojileri ve materyal tasarımı (pp. 115-141). Ankara: Pegem Akademi.

Koç, H., Aksoy, B. \& Çiftçi, T. (2017). An examination of map literacy levels of students from various undergraduate programmes according to several variables: Cumhuriyet University Sample. Erzincan University Journal of Education Faculty, 19(3), 301-321.

Koç, H., Aksoy, B. (2009) Sosyal bilgiler öğretimi. In M. Safran (Eds.), Harita becerileri ve 1114 yaş grubundaki ögrencilerin yapabilecekleri harita becerileri (pp. 341-360). Ankara: Pegem.

MoNE (Ministry of National Education), (2005a). Coğrafya dersi öğretimi programı (9., 10., 11. ve 12. grades). Ministry of National Education, Head Council of Education and Morality, Ankara.

MoNE, (2006). İlköğretim 6.sınıf sosyal bilgiler dersi öğretim programı kılavuzu, Ankara

Otluoğlu, R. \& Öztürk C., (2003) Sosyal bilgiler öğretiminde edebi ürünler ve yazılı metinler. Ankara: Pegem.

Sarıgöz, O., Özkartal, Z., Dönger, A., Cam, F. \& Koca, M. (2015) Vocational college students' evaluation of comments and thoughts on the applied learning. The Third International Congress on Curriculum and Instruction, Cukurova University, 22-24.

Sönmez, Ö. F. \& Aksoy, B. (2013). Map skills and present of Republic elementary school curricula. The Journal of Turkish Social Research, 17(1), 269-288.

Sönmez, Ö.F. (2010) Map skills in primary schools social studies education (Unpublished Doctoral Dissertation). Institute of Educational Sciences, Gazi University, Ankara, Turkey.

Ünlü, M, Üçışık, M., Özey, R. (2002). The importance of the maps in geography education and instruction. International Journal of Geography and Geography Education, 5, 9-25.

Ünlü, M. (2011). The level of realizing geography skills in geography lessons. Educational Sciences: Theory and Practice, 11(4), 2155- 2172.

Zaman, S., Günal, H. \& Zaman, N. (2011). A research on history teachers views on map use: Erzurum sample. Atatürk University Journal of Social Sciences Institute, 15(2), 205218.

\section{Biographical Statement}

Servet HALI is an Assoc. Prof. at the faculty of education, Hatay Mustafa Kemal University, Turkey. She works on social studies education. 